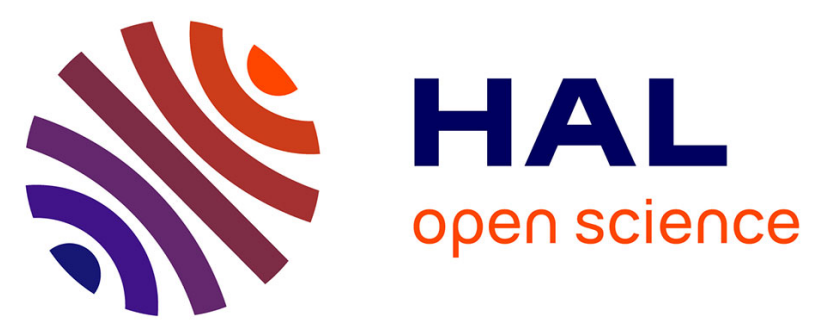

\title{
Fenprostalene in cattle: evaluation of oxytocic effects in ovariectomized cows and abortion potential in a 100-day pregnant cow
}

Rafael Garcia Villar, Pierre-Guy Marnet, M.P. Laurentie, P.L. Toutain

\section{- To cite this version:}

Rafael Garcia Villar, Pierre-Guy Marnet, M.P. Laurentie, P.L. Toutain. Fenprostalene in cattle: evaluation of oxytocic effects in ovariectomized cows and abortion potential in a 100-day pregnant cow. Theriogenology, 1987, 28 (4), pp.467-480. hal-02723215

\section{HAL Id: hal-02723215 \\ https://hal.inrae.fr/hal-02723215}

Submitted on 1 Jun 2020

HAL is a multi-disciplinary open access archive for the deposit and dissemination of scientific research documents, whether they are published or not. The documents may come from teaching and research institutions in France or abroad, or from public or private research centers.
L'archive ouverte pluridisciplinaire HAL, est destinée au dépôt et à la diffusion de documents scientifiques de niveau recherche, publiés ou non, émanant des établissements d'enseignement et de recherche français ou étrangers, des laboratoires publics ou privés.

\section{다(1)(2)}

Distributed under a Creative Commons Attribution - ShareAlikel 4.0 International 


\author{
FENPROSTALENE IN CATTLE: \\ EVALUATION OF OXYTOCIC EFFECTS IN OVARIECTOMIZED COWS AND \\ ABORTION POTENTIAL IN A 100-DAY PREGNANT COW \\ R. Garcia-Villar, P.G. Marnet, M.P. Laurentie and P.L. Toutain \\ Institut National de la Recherche Agronomique \\ Department of Pharmacology \\ F - 31300 TOULOUSE - FRANCE \\ Received for publication: August 8, 1986 \\ Accepted: Juty 27, 1987
}

\begin{abstract}
Four ovariectomized cows were used to compare the uterotonic coxytocic) properties of the prostaglandins $F 2 \alpha$ analogue fenprostalene to clo-

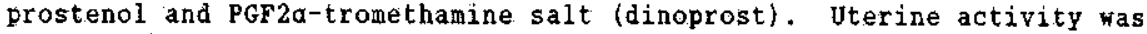
measured by electromography with the duration and magnitude of activity quantified by microcomputer. The administration of $1 \mathrm{~kg}$ of fenprostalene to estradiol primed animals significantly increased uterine motility for approximately $19 \mathrm{~h}$. This was significantly longer than the duration observed for either cloprostenol $(500 \mu \mathrm{g}, 3 . \mathrm{m},, 8.9 \mathrm{~h})$ or dinoprost (25 $\mathrm{mg}, i . \mathrm{m.}, 7.7 \mathrm{~h}$ ). However, the level of activity was similar for the 3 compounds tested, with postinjection levels of oxytocic effect averaging 369 for treated animals compared to 100 for controls. Therefore, the difference in effects for the three prostaglandins may be due more to pharmacokinetic properties rather than to different potencies of the three compounds.

In addition, à pregnant cow (100 d gestation) was treated with fenprostalene (1 $\mathrm{mg}, \mathrm{s.c.}$ ). Fenprostalene treatment resulted in unchanged uterine activity for a 6 -h period, followed by a four-fold increase in genital tract activity which lasted for $12 \mathrm{~h}$. Thereafter, activity was inhibited for one day, followed by a sharp increase in uterine activity leading to abortion within 66 to $72 \mathrm{~h}$ after fenprostalene injection. The placenta was expelied 7 days after treatment.
\end{abstract}

Keywords: fenprostalene, prostaglandin F2a, uterine motility, cattle.

Acknowledgements

The authors gratefully thank Drs. J.F.S. Reid, R.C. Herschler and R. Schiltz of Syntex Research, Palo Alto, CA, for their critique. 


\section{INTRODUCTION}

Prostaglandins of the $F 2$ alpha type (PGF2a) are routinely used for reproductive management in dairy and beef cattle as estrus-control agents (1-3) for termination of unwanted pregnancies (4) and for the treatment of various reproductive diseases such as luteal cysts, pyometra and endometritis (5).

In field trials, Herschler et al. (6) reported that fenprostalene, a long-acting analogue of PGF $2 a$, gave a higher rate of successful abortions than natural PGF2a, especially when given to cattle pregnant between 100 and $150 \mathrm{~d}$. In a previous work on sheep (7), it was found that fenprostalene exerted far longer oxytocic effects than either dinoprost or cloprostenol. It was therefore suggested that both the lutaolytic and long-acting oxytocic properties of fenprostalene could be responsible for its high efficacy in inducing abortion after $100 \mathrm{~d}$ of gestation in the bovine species. Our hypothesis, based upon observations made by others in the guinea-pig (8) and measurements of the PGF metabolite 15-keto-13,14 dihydro-PGFa in cattle (22), was that, in addition ot its luteolytic effect, fenprostalene induced sustained increases in uterine motility after $100 \mathrm{~d}$ of pregnancy and damaged the physical connections between the chorion and caruncles of the endometrium, which resulted in abortion through the release of endogenous prostaglandins. Nevertheless, definite data concerning the oxytocic properties of fenprostalene in cattle are lacking in the iiterature.

Uterine motility studies in the bovine have been conducted using a variety of techniques including the use of intraluminal rubber balloons $(9,10)$ or electrodes clipped into the uterine wall through the cervix (11). These method were unsuitable to accurately evaluate spontaneous and/or drug-induced motility changes over a prolonged period of time.

Conversely, electromyographic techniques using electrodes chronically implanted into the myometrial wall $(12-15)$ seemed relevant for use, especially when studying long-acting drugs. On the other hand, the oxytocic effects of drugs have been shown to be dependent on the stage of the estrous cycle: mometrial responsiveness being maximal at estrus $(12,13)$. preliminary studies in ovariectomized cows deprived of estradiol priming and/or bearing progestagen impregnated vaginal sponges showed that neither fenprostalene nor dinoprost were able to stimulate uterine motility under those hormonal conditions. Conversely, clear oxytocic responses were observed when either prostaglandins were injected into the same cows after estradiol priming.

Therefore, the purpose of this study was to electromyographically evaluate the relative oxytocic effects of the recommended therapeutic doses of fenprostalene, cloprostenol and dinoprost in ovariectomized cows primed with exogenous $17 \beta$-estradiol. In addition, the oxytocic andor abortive capabilities of a single injection of fenprostalene was ascertained in a cow pregnant for $100 \mathrm{~d}$. 
Five healthy adult cows of the Francaise Frisonne Pie Noire breed, weighting $532 \pm 40 \mathrm{~kg}$, were used in our study. After $24 \mathrm{~h}$ fasting, the cows were tranquilized with xylazine hydrochloride, a injected intramuscularly $(0.1 \mathrm{mg} / \mathrm{kg})$ and given both epidural and local anesthesia with lidocaine hydrochloride.b Under aseptic surgical conditions, the cows were subjected to a flank laparotomy just anterior to the tensor fascia lata on either the right or the left side. Four of the cows, which were nonpregnant, were then bilaterally avariectomized (OVX). The fifth, which was pregnant, was left intact. Electrodes similar to those described by Ruckebusch and Bayara (12) were positionned in groups of three at different sites on the greater curvature of at least one uterine horn. For the pregnant cow, two groups were implanted on the empty horn and four on the gravid horn.

After surgery, the cows were placed in individual stalls and fed a nortal diet of hay and concentrates in two daily meals at 8:00 a.m. and 4:00 p.m. Water was available ad Iibitum.

Electrodes were connected to the recorder using an extension cable which allowed animal movenents with minimua artifacts.

Uterine electromyograns (EMG) were obtained on a multichannel ampiifier polygraph that allowed direct recordings (time constant: 0.1 sec, paper speed: $3.6 \mathrm{~cm} / \mathrm{min}$ ) used discretionally as a control of the quality of EMG. In addition, EMG signals were continuously integrated as a monitoring procedure and displayed $24 \mathrm{~h} / \mathrm{d}$ on a potentiometric recorder (paper speed: $1 \mathrm{~mm} / \mathrm{min})$. This integrated EMG was automatically quantified using an on-line microcomputer, and activity level was measured by 10-min epochs and expressed in arbitrary computer units (c.u.).

Design of study in ovx cows

The four ovariectomized cows were given at $2-3$ day intervals a single i.m. injection of $17 \beta$-estradiole (1 $\mu \mathrm{g} / \mathrm{kg})$, followed within 15 and $19 \mathrm{~h}$ later, by one of the prostaglandin treatments. Order of treatment was randomized and different across the four cows. The following analogues of PGF2 $\alpha$, referred to as test articles, were used: tenprostalene, dinoprost tromethamol' aná cloprostenol ${ }^{\text {. }}$.

- Rompun, Bayer, Puteaux, France.

b Lucrocaine, Vetoquinol, Lure, France.

- Minihuit, Alvar, Hontreuil, France.

d CR553, JJLLOYD Instruments, Southampton, United Kingdom.

- 17ß-estradiol, Sigra Chem., St-Louis, Mo., in ethanol solution (1 $\mathrm{mg} / \mathrm{mI}$ ).

\$ Synchrocept B, Syntex Agribusiness, Louvain-la-Neuve, Belgium.

- Dinolytic, The Upjohn Co., Paris, France.

b Estrumate, ICI Pharma, Enghien, France. 
Each prostaglandin treatment was administered at least three times to each of the four cows according to the recommended dose and route, $i . e$. fenprostalene (1 $\mathrm{mg}$ total dose) was injected s.c. (skin of the neck), dinoprost (25 mg total dose) and cloprostenol (500 $\mu \mathrm{g}$ total dose) were injected deep into the gluteus muscle. In addition, in two of the ovx cows. fenprostalene ( $1 \mathrm{mg}$ total dose) was injected three times each by the i.m. route.

Evaluation of the oxytocic effects of the test articles was performed according to the following scoring method; a representative control period of four consecutive hours was selected by visual inspection of the charts from the $8 \mathrm{~h}$ preceding test-article injection. The mean $\pm \mathrm{SD}$ control activity level (expressed in c.u.) was then calculated from these 24, 10 -min periods and considered as $100 \%$.

A threshold value (referred to as a "keY" value) corresponaing to the control mean +1 S.D., was then valculated. Significant oxytocic effects were determined, taking into account the post injection periods during which activity levels were higher than, or equal to, this "key".

Statistical calculations were performed using one-way analysis of variance by ranks (Kruskal-Wallis) and Mann-Whitney test.

Design of study in pregrant cow

Only one con, which was pregnant 67 at the time of surgery, was used in this study. At 100 d of gestation, the cow was given fenprostalene as recommended ( 1 ing. s.c.), Uterine aMGs were continuously recorded and quantified. In addition, the luteolytic capability of fenprostalene was assessed by blood progesterone (16) and estrogens (17). Jugular vein blood samples were collected into chilled heparinized tubes at fenprostalene preinjection minutes $60,45,30$ and 15 and at postinjection hours 1 to $12,23,24,25,28,30,48,52,56,72,80$ and 120 . Samples vere rapidy centrifuged and stored at $-20^{\circ} \mathrm{C}$ until assayed.

\section{RESULTS}

Study in ovariectornized cows

Controls motility patterns. Spontaneous motility was absent in the uterus of cows deprived of estradiol. In contrast, motility was promoted when animals were given estradiol. The dosage regimen used throughout these experiments (1 $\mu \mathrm{g} / \mathrm{kg}$, i.m.) allowed the onset of notility events after an average delay of $7 \mathrm{~h}$, mainly in the form of discrete episodes of 6 to 8 min duration, occurring at approximately hourly intervals and called regular activity. Between two such episodes, activity was often present in the form of randomly-occurring spiking activity called irregular activity. 
Effects of prostaglandins treatments: qualitative aspects. Fenprostalene, as well as dinoprost and cloprostenol, led to a dramatic increase in the frequency of occurrence of regular activity episodes and/or to the enhancement of irregular activity. Speeding up of reguiar activity was more likely the response to the s.c. injection of fenprostalene. In contrast, almost continuous activity was generally observed after i.m. injections of either fenprostalene, cloprostenol or dinoprost (Figure 1).

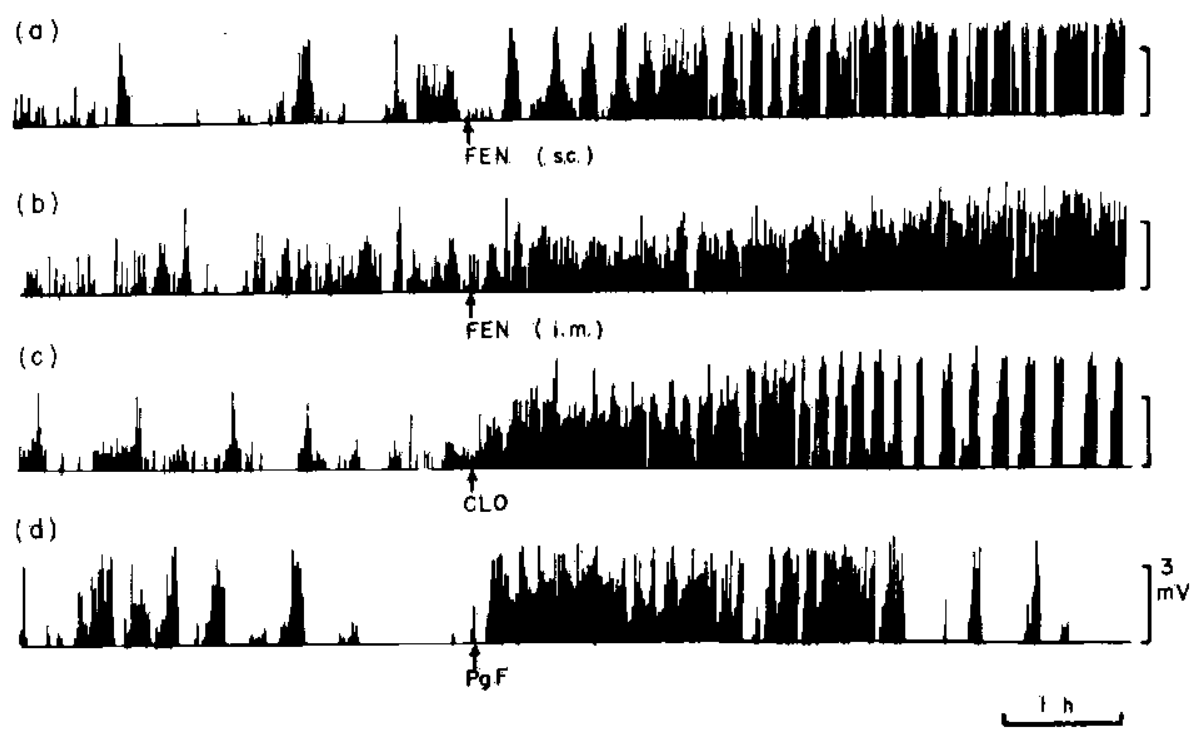

Fígure 1. Enhancement of uterine motility after single injections of test articles: fenprostalene (fen: (a) s.c. and (b) i.m.), (c) cloprostenol (clo, i.t.) and (d) dinoprost (pgf, i.m.). A slightly delayed discrete response pattern was of ten observed after s.c. injection of fenprostalene; an almost continuous activity pattern was the immediate response to i.m. injections.

\section{Effects of prostaglandin treatments: quantitative aspects.}

1) Oxytocic effects were expressed in terms of duration and magnitude of drug action. A standardized scoring method was employed using the activity values given by the microcomputer at each 10 -min period. For each injection of test article included in the full study, eight variables (V1 to V8) were calculated to characterize the parameters of the oxytocic response: a) five time-parameters: $v 1$ = delay of onset of the oxytocic 
response $; \mathrm{V} 2$ = total duration of oxytocic response, calculated from the sum of the following 3 phases; $V 3=$ early discrete response (neglected in final results) ; $\mathrm{V4}=$ duration of continuous response ; $\mathrm{V5}=$ duration of late discrete response: b) three magnitude-parameters: V6 = magnitude of continuous response; $V 7=$ magnitude of discrete resonse $; ~ v 8$ = total oxytocic effect $; \mathrm{V} 8=(\mathrm{V} 4 \times \mathrm{V} 6)+(\mathrm{V} 5 \times \mathrm{V} 7)$.

The meaning of each variable is presented with a graphic example (Figure 2). The relative oxytocic effects of fenprostalene (s.c. and i.m.), cloprostenol and dinoprost are also shown (Tables 1 and 2 ).

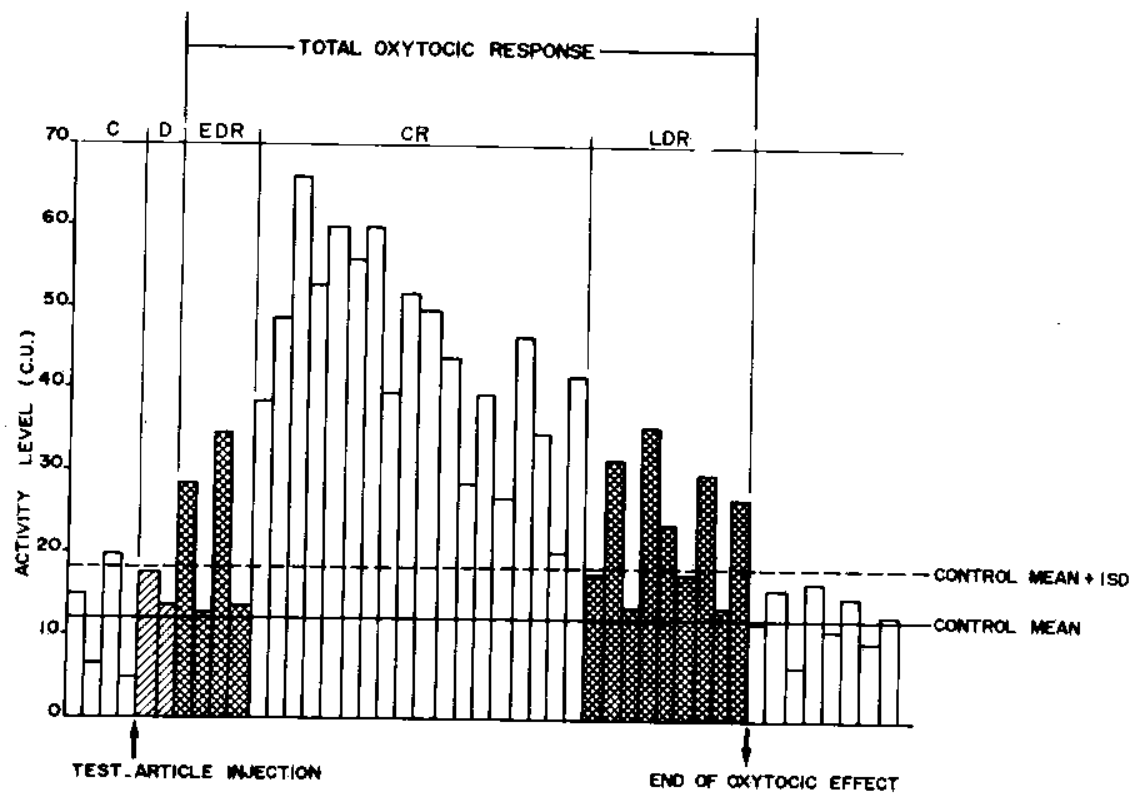

Figure 2. Graphic example of the scoring procedure. Oxytocic response paraweters were characterized using the activity values given periodically by the microcomputer (c.u.: computer units). Values higher than control thean + 1 S.D. ("key" value) were considered as significant oxytocic responses. Duration and magnitude of the different phases of the oxytocic response vere calculated: $\mathrm{C}=$ control, $\mathrm{D}=$ delay, $\mathrm{EDR}=$ early discrete response, $\mathrm{CR}=$ continuous response, LDR = late discrete response. 
Table 1. Characteristics of oxytocic effect parameters (mean \pm SD values) for the four treatments. Parameters of time are in hours; parameters of magnitude are in (control level $=100 *$ see text and Figure 2 for definitions and Table 3 for statistics).

Oxytocic Response

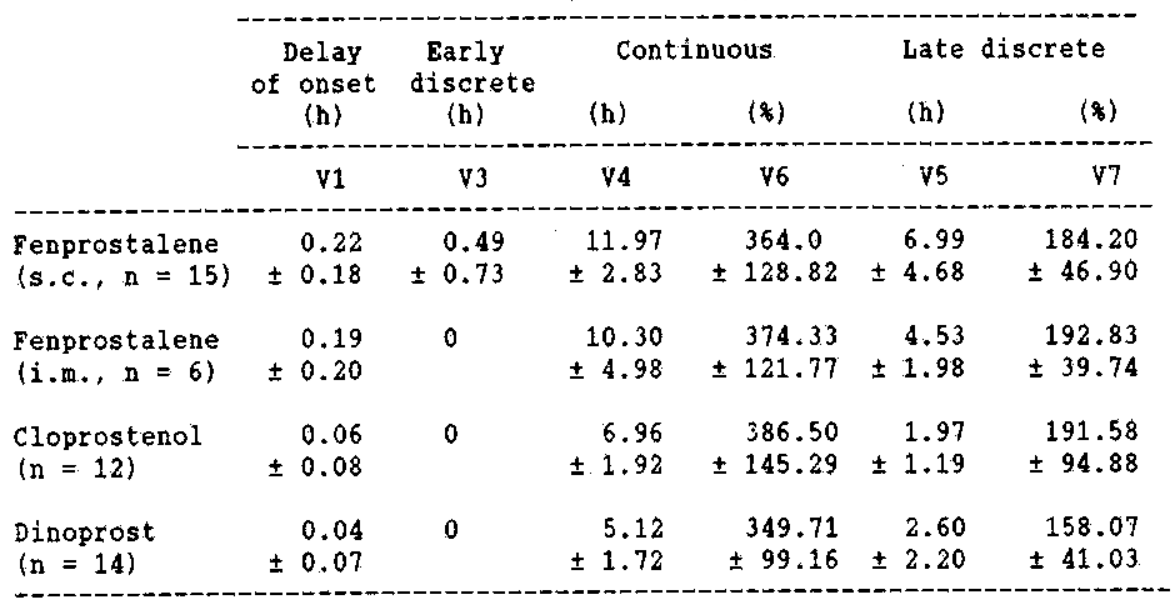

Table 2. Relative oxytocic effects of recommended therapeutic doses of fenprostalene (s.c. and i.m.), cloprostenol and dinoprost (mean \pm SD) in ov cows under estradiol priming. Effects of the latter test article have been taken as reference to calculate the ratios (see text and Figure 2 for definitions and Table 3 for statistics).

Total oxytocic response

\begin{tabular}{|c|c|c|c|}
\hline & $\begin{array}{l}\text { Duration } \\
\text { (h) }\end{array}$ & Duration $x$ Magnitude & Ratio \\
\hline & V2 & V8 & \\
\hline $\begin{array}{l}\text { Fenprostalene } \\
\text { (s.c., n }=15 \text { ) }\end{array}$ & $\begin{array}{r}18.91 \\
\pm \quad 5.73\end{array}$ & $\begin{array}{r}5767.84 \\
\pm \quad 2516.27\end{array}$ & 2.624 \\
\hline $\begin{array}{l}\text { Fenprostalene } \\
(i . m, n=6)\end{array}$ & $\begin{array}{r}14.84 \\
\pm \quad 4.73\end{array}$ & $\begin{array}{r}5092.30 \\
\pm \quad 2889.70\end{array}$ & 2.316 \\
\hline $\begin{array}{l}\text { Cloprostenol } \\
(\mathbf{n}=12)\end{array}$ & $\begin{array}{r}8.91 \\
\pm 1.89\end{array}$ & $\begin{array}{r}3198.50 \\
+1754.88\end{array}$ & 1.455 \\
\hline $\begin{array}{l}\text { Dinoprost } \\
(\mathrm{n}=14)\end{array}$ & $\begin{array}{r}7.72 \\
\pm \quad 3.13\end{array}$ & $\begin{array}{r}2198.50 \\
\pm \quad 831.43\end{array}$ & 1.000 \\
\hline
\end{tabular}

arbitrary unit. 
2) Comparisons among treatments were performed using appropriate statistical tests.

The delay of action (V1) was not different for fenprostalene s.c. and fenprostalene i.m. $(P=0.05)$, whereas the effects of dinoprost and cloprostenol were significantly more rapid $(P<0.01)$.

The total duration of oxytocic effects (V2) of fenprostalene after s.c. administration was significantly longer than the duration of effects of either cloprostenol or dinoprost $(P<0.01)$. In contrast, the duration of oxytocic effect after i.m. injection of fenprostalene was shorter than after s.c. injection but not significantly (P>0.05).

Total oxytocic activity (V8) was significantly different anong the four treatments (Kruska1-Wallis test; $P(0.001)$. Fenprostalene s.c. led to the highest value and dinoprost to the lowest. If dinoprost, which is closer to the natural hormone, was taken as a unit, a therapeutic dose of fenprostalene (s.c.) was 2.6 times more oxytocic, while cloprostenol was only 1.5 times more oxytocic than dinoprost (Table 2).

For the other variables, similar comparisons were performed anong treatments. No significant differences existed for fenprostalene according to the route of administration. In contrast, effects of fenprostalene (s.c.) differed from the effects of both other prostaglandins, except for magnitude of effects (Table 3 ).

Table 3. Significance level of the statistical test (Mann-Whitney) used to compare the effects of fenprostalene (s.c.) with the other test articles, i.e. fanprostalene (i.m.), cloprostenol and dinoprost. Definition of variables $V 1$ to $V 8$ is available in text.

\begin{tabular}{|c|c|c|c|c|}
\hline Paramet & & Fenprostalene (i.m.) & Cloprostenol & Dinoprost \\
\hline Titme & V1 & ns & $P<0.01$ & $P<0.01$ \\
\hline & v2 & ns & $P<0.01$ & $P<0.001$ \\
\hline & V3 & - & - & - \\
\hline & V4 & ns & $P<0.001$ & $P<0.001$ \\
\hline & V5 & ns & $P<0.001$ & $P<0.01$ \\
\hline Magnitude & v6 & ns & $\mathrm{ns}$ & ns \\
\hline & v7 & ns & ns & ns \\
\hline Total & V8 & ns & $P<0.01$ & $P<0.001$ \\
\hline
\end{tabular}

ns $=$ not significant $(P>0.05)$.

Study in the pregnant cow

Uterine contractility before fenprostalene injection. Electromyographic records started at Day 84 of gestation, 16 d after electrodes implantation. From that time until Day 90, an almost flat record was obtained, suggesting absence of contractions in the bovine pregnant uterus. Nevertheless, between Days 91 and 94 , a few strong nonsitultaneous, random, episodes of activity were recorded on the pregnant horn, at some electrode 
sites (two to six episodes $/ 24 \mathrm{~h}$ ). Between Days 95 and 100 , the frequency of occurrence of such episodes progressively increased, with an average of $9 / 24 \mathrm{~h}$ and their periodicity was more regular throughout the nycthemere $(2.35 \pm 1.08 \mathrm{~h})$. These episodes resembled those recorded in the estrogen primed ovX cows and were therefore called regular activity episodes. Between two such episodes random activity occurred and was labeled irregular activity (Figure 3 ).

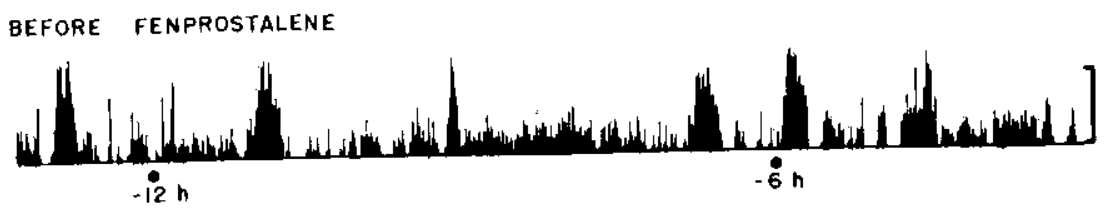

AFTER FENPROSTALENE

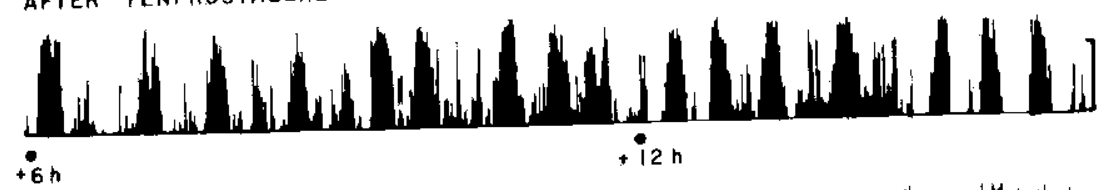

$+6 h$
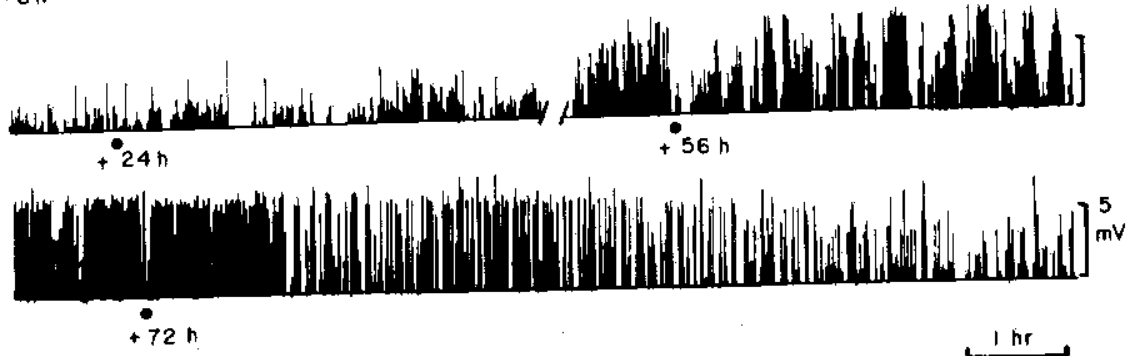

Figure 3. Activity pattern recorded on the pregnant uterine horn of a 100d pregnant cow, before and after fenprostalene injection (time 0 not shown). The frequency of occurrence of regular activity episodes was markedly increased from the 6 th to the 18 th hour postinjection as compared to preinjection controls. Abortion occurred around 72 hrs after fenprostalene during a phase of intense activity, immediately followed by a sharp drop in motiiity.

Activity patterns after fenprostalene administration. Primary oxytocic effect: fenprostalene given at Day 100 of gestation markedly enhanced the number of activity episodes (Figure 3). oxytocic effects started after a delay of $6 \mathrm{~h}$ and lasted for $11.50 \mathrm{~h}$, during which 19 episodes were recorded at the most electromyographically active electrode site, a $4.2-$ time increase when compared with 9 episodes $/ 24$ h recorded the day before fenprostalene. 
Secondary inhibition phase : a prolonged phase of relatively lower activity followed this early oxytocic effect. Throughout this phase, which lasted about one day $(25.17 \mathrm{~h})$, episodes of activity were not recorded. Only a low level irregular activity was still present and tended to increase progressively during the second half of this period.

Activity at the time of abortion : activity levels were raised dramatically during the following $30 \mathrm{~h}$, and both regular and irregular activities were present. Computer values obtained between 66 and $72 \mathrm{~h}$ postinjection showed a 5-fold increase compared with preinjection controls (143 \pm 25 vs $29 \pm 12$ c.u./h). At this time some uterine contents were expelled and subsequently activity levels dropped dramatically but only for 8 to 12 h. Indeed, a new dramatic increase (up to 6 times preinjection values) occurred within 12 to $18 \mathrm{~b}$ after abortion. This high-level activity persisted for 3 days. On the fourth day, $7 \mathrm{~d}$ after fenprostalene, the placenta was expelled and then activity rapidly disappeared. The uterus remained quiescent until the first estrus, $14 \mathrm{~d}$ after abortion.

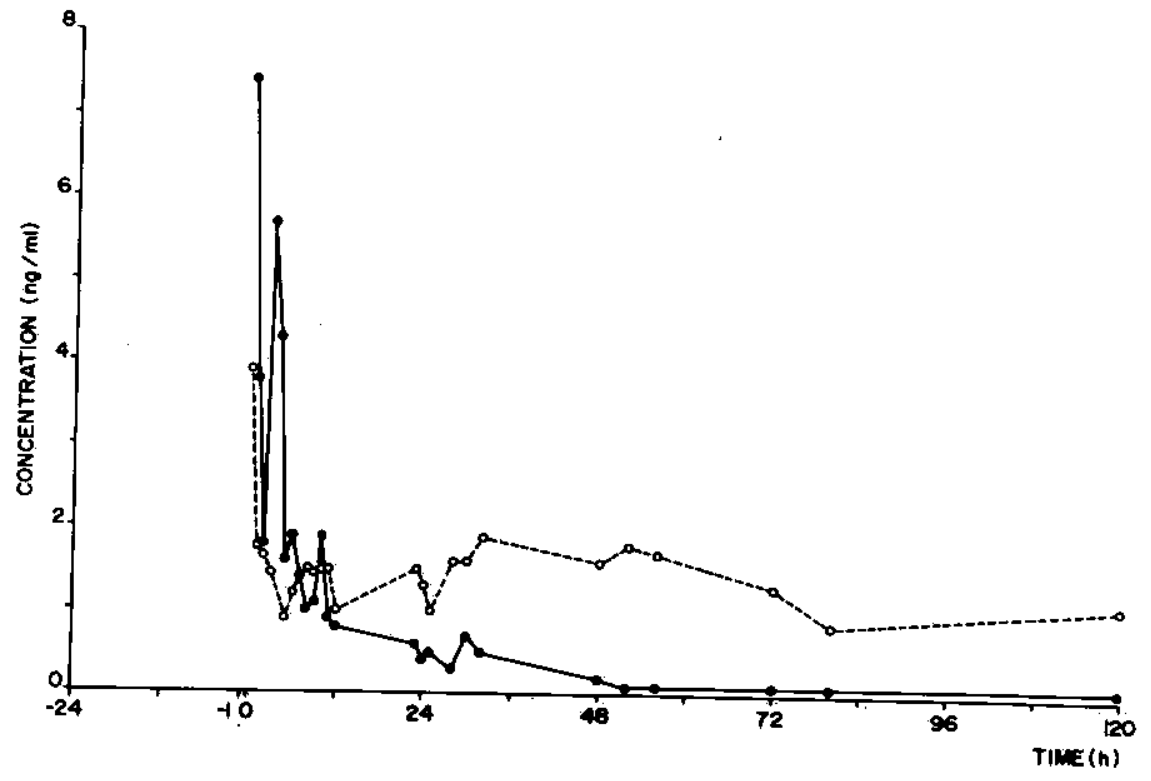

Figure 4. Plasma levels of progesterone (-—) and total estrogens (a---o) after a single injection of fenprostalene ( $1 \mathrm{mg}, \mathrm{s}, \mathrm{c}$. to a 100-d pregnant cow. A sharp drop in progesterone levels was achieved within $5 \mathrm{~h}$ postinjection.

Luteolytic effects of fenprostalene. Plasma levels of progesterone and total estrogens before and after fenprostalene are shown (Figure 4). A sharp drop in progesterone levels was observed within $5 \mathrm{~h}$ after fenprostalene, indicating the rapid onset of luteolysis. In contrast, evident changes in total estrogens were not observed. 


\section{DISCUSSION}

At the recommended therapeutic doses, the three prostaglandins developed clear-cut uterotonic (oxytocic) effects in ovariectomized cattle under estradiol priming. The longest oxytocic action was obtained with fenprostalene given s.c., whereas activity levels attained within the duration of oxytocic effects were similar for the three prostaglandins. Consequently, it is likely that the difference in the overall oxytocic effects were related more to pharmacokinetic properties rather than to different potencies of the three compounds.

In this respect, available pharmacokinetic data indicate an elimination half-life of $3 \mathrm{~h}$ for cloprostenol after i.m. injection of $500 \mathrm{\mu g}$ to cattle (18). Similarly, a plasma half-1ife of $2.5 \mathrm{~h}$ was calculated for PGF2a-Tham after i.m. injection of $25 \mathrm{mg}$ to cattle (19). Both doses were identical to those used in this study. The half-life value calcuiated for fenprostalene in polyethylene glycol 400 vehicle after s.c. administration of $1 \mathrm{mg}$ to cattle was about $24 \mathrm{~h}(6)$. Such kinetic values tentatively explained the longer-acting effect of fenprostalene.

The oxytocic effects of therapeutic doses of the three prostaglandins were more than twice as long in cattle than reported in ovariectomized estrogen treated ewes (18.95 vs $8.52 \mathrm{~h} ; 7)$. Nevertheless, their relative ranking was respected, i.e. fenprostalene $>$ cloprostenol, dinoprost.

When given to a cow pregnant for $100 \mathrm{~d}$, fenprostalene possessed both oxytocic and abortive capabilities. According to available data from pregnant ewes $(20,21)$ which showed that the pregnant uterus is quiescent during about the first third of gestation, it can be supposed that the appearence of activity episodes within Days 90 to 100 corresponded to the actual time of physiologic onset of motility in the bovine pregnant uterine horn. Indeed, this stage of gestation corresponded to onset of massive local releases of estrogens by the uteroplacental unit and the strengthen-

ing of the connections between the chorion and the caruncles of the endometrium $(23,24)$. Presence of $10 \mathrm{cal}$ amounts of estrogens in the myometrium allowed uterine responsiveness to oxytocic drugs such as prostaglandins of the ras type.

The direct uterine contractile effect of fenprostalene lasted for approximately $12 \mathrm{~h}$ in our study on one pregnant cow. This oxytocic effect appeared to start after a latency of $6 \mathrm{~h}$. In fact, this lag-time corresponded to the decay of plasma progesterone levels from the normal values recorded during pregnancy (about $8 \mathrm{ng} / \mathrm{ml}$ ) to values lower than $2 \mathrm{ng} / \mathrm{ml}$. It can be supposed that high circulating progesterone levels prevented the onset of fenprostalene-induced oxytocic effects, which corresponds to the results of our preliminary experiments. The fact that fenprostalene was a long-acting oxytocic PGF $2 a$ analogue (about $19 \mathrm{~h}$ ), according to the results of our study in estrogen-primed ovx cows, allowed the re-energence of an oxytocic stimuius once progesterone decline was achieved and the enhancement of uterine activity from the 6 th to the 18 th postinjection. It is probable that a prostaglandin analogue with a shorter duration of action would be less effective in inducing myometrial contractions, at least when administered as a single injection, and would probably necessitate repeat-ed injections to produce an oxytocic effect similar to that observed in our study after a single injection of fenprostalene. 
In this respect, it can be emphasized that shorter acting prostaglandins analogues like cloprostenol have been shown to be highly effective in inducing luteolysis and subsequently abortion when given before pregnancy Days 150 to $160(22)$. Our hypothesis, which neek further investigation, was that long-lasting stimulation of myometrial contractions, like those induced by fenprostalene, could be decisive in efficiently promoting abortion and uterine emptying during later stages of pregnancy.

Indeed, according to Lindell et al. (22), who measured 15-keto-13,14 dihydro PGF $2 \alpha$ in pregnant cattle that were given cloprostenol, it can be suggested that the long-lasting oxytocic effects of fenprostalene may have caused enough damage to the uteroplacental connections to provoke the release of massive amounts of endogenous prostaglandins: the higher the contractions, the higher the release of oxytocic prostaglandins and viceversa, Finally, in our study, abortion occurred within 66 to $72 \mathrm{~h}$ during a phase of intense activity, probably under the oxytocic influence of great amounts of endogenous prostaglandins.

In conclusion, due to its long-acting oxytocic properties, fenprostalene appeared to be suitable for increasing uterine motility in cattle under different endocrine conditions such as pregnancy beyond the 100 to 150 th $d$ of gestation (presence of both estrogens and progesterone) or estrus (estrogen domination). Therefore, fenprostalene would probably be of interest in bovine veterinary practice when evacuation of uterine contents is required.

\section{REFERENCES}

1. Seguin, B.E. Role of prostaglandins in bovine reproduction. J. Am. Vet. Med. Assoc. 176:1178-1181 (1980).

2. Seguin, B.R., Tate, D.J. and Otterby, D.E. Use of cloprostenol in a reproductive management system for dairy cattle. J. Am. Vet. Med. Assoc. 183:533-537 (1983).

3. Herschler, R.C. Estrus synchronization and conception rates in beef heifers using fenprostalene in both single- and double- injection programs. Agri-practice $4: 28-31$ (1983).

4. Day, A.M. Cloprostenol for termination of pregnancy in cattle. $N$. 2. Vet. J. $25: 136-144$ (1977).

5. Rudd, R. and Kopcha, M. Therapeutic use of prostaglandin F2a. J. Am. Vet. Ked. Assoc. 181:932-934 (1982).

6. Herschler, R.C., Kent, J.S. and Tomlinson, R.V. New prostaglandins: Present studies and future, In: Ruckebusch, Y., Toutain, P.L. and Koritz, G.D. (eds.). Veterinary Pharmacology and Toxicology. MTP Press Ltd, United Kingdom, 1983, pp. 213-220.

7. Garcia-Villar, R., Marnet, P.G., Laurentie, M.P. and Toutain, P.L. Relative oxytocic properties of fenprostalene compared with cloprostenol, prostaglandin F2a, and oxytocin in the ovariectomized eve. Am. J. Vet. Res. 46:841-844 (1895). 
8. Elger, W. Pharmacology of parturition and abortion. Anim. Reprod. Sci. 2:133-148 (1979).

9. Hays, R.L. and Van Demark, N.L. Spontaneous motility of the bovine uterus. Am. J. Physiol. 172:553-556 (1953).

10. Eiler, K., Oden, J., Schaub, R, and Sims, M. Refractoriness of both uterus and mammary gland of the cow to prostaglandin $F 2 \alpha$ administration: clinical implication. Am. J. Vet. Res. 42:314-317 (1981).

1. Chen, T.W., MacDonald, M.A. and Hawes, R.O. Mechanical and electrical activities of the female bovine genital tract in vivo. Can. J. Anim. Sci. 46:25-29 (1966).

12. Ruckebusch, Y, and Bayard, F. Motility of the oviduct and uterus of the cow during the oestrous cycle. J. Reprod. Fertil. 43:23-32 (1975).

13. Taverne, M.A.M., Van der Weyden, G.C. and Fontijne, P. Preliminary observations on mometrial electrical activity before, during and after parturition in the cow. In: Hoffman, B., Nason, I.L. and schmidt J. (eds.). Calving Problems and Early viability of the Calf. Current Topics in Veterinary Medicine and Animal Science $4: 297-311$ (1979).

14. Hanzen, $c$. Electrical activity of the bovine uterus prior to and post parturition. Vet. Res. Commun. 5:143-150 (1981).

15. Zerobin, K. Die Uterusmotorik wahrend der Brunst beim Rind. Tierärztl. Umschau. $\underline{40: 438-442}(1985)$.

16. Saumande, J., Tamboura, D. and Chupin, D. Changes in milk and plasma concentrations of progesterone in cows after treatment to induce superovulation and their relationships with number of ovulations and of embryos collected. Theriogenology $23: 719-731$ (1985).

17. Saumande, J. Radioimmunoassay of oestradiol-17ß in unextracted ewe plasma. Steroids 4:425-437 (1981).

18. Reeves, P.R. Distribution, elimination and residue studies in the cow with the synthetic prostaglandin estrumate. J. Agric. Food Chem. $26: 152-155$ (1978).

19. Neff, A.W., Ruppel, C.C., Gasline, R.E., Jaglan, P.S. and McGrath, P.S. PGr2a residue studies in beef and dairy cattle. Acta Vet. Scand. Suppl. 77:11-27 (1981).

20. Van der Weyden, G.C., Taverne, M.A.K., Dieleman, S.J. and Fontijne, P. Myometrial electrical activity throughout the entire course of pregnancy in the ewe. Eur. J. Obstet. Gynaecol. Reprod. Biol. 11:195204 (1981).

21. Garcia-Villar, R, Toutain, P.L, and Ruckebusch, Y. Patterns of electrical activity of the ovine uterus and cervix from mating to parturition. J. Reprod. Fertil. 72:143-152 (1984). 
22. Copeland, D.D., Schultz, R.H. and Kemtrup, M.E. Induction of abortion in feedlot heifers with cloprostenol (a synthetic analogue of PGF2a) : a dose response study. Can. Vet. J. 19:29-32 (1978).

23. Robertson, H.A. and King, G.J. Conjugated and unconjugated oestrogens in fetal and maternal fluids of the cow throughout pregnancy. $J$. Reprod. Fertil. 55:463-470 (1979).

24. Lindel1, J.0., Kindahl, H. and Edqvist, L.E. Prostaglandin induced eariy abortion in the bovine: clinical outcome and endogenous release of prostaglandin F $2 a$ and progesterone. Anim. Reprod. Sci. 3:289-299 (1980-1981). 

